\title{
Determining elements of variety-specific maize production technology
}

\author{
Mihály Sárvári - Beáta Boros \\ University of Debrecen Centre for Agricultural and Applied Economic Sciences, Institute of Crop Sciences, 4032 Debrecen 138 \\ Böszörményi St., sarvari@agr.unideb.hu
}

Keywords: variety-specific, fertilization, sowing time, plant density

SUMMARY

\begin{abstract}
Our aim was to work out such new maize fertilizer methods and models which can reduce the harmful effects of fertilization, can maintain the soil fertility and can moderate the yield fluctuation (nowadays 50-60\%).

The soil of our experimental projects was meadow soil. The soil could be characterized by high clay content and pour phosphorus and medium potassium contents. In the last decade, out of ten years six years were dry and hot in our region. So the importance of crop-rotation is increasing and we have to strive for using the appropriate crop rotation.

The yields of maize in monoculture crop rotation decreased by 1-3 $t$ ha-1 in each dry year during the experiment (1983, 1990, 1992, 1993, 1994, 1995, 1998, 2000, 2003, and 2007). The most favourable forecrop of maize was wheat, medium was the biculture crop rotation and the worst crop rotation was the monoculture.

There is a strong correlation between the sowing time and the yield of maize hybrids, but this interactive effect can be modified by the amount and distribution of precipitation in the vegetation period. At the early sowing time, the grain moistures were 5-12\% lower compared to the late sowing time and 4-5\% lower compared to the optimum sowing treatment.

There are great differences among the plant density of different maize hybrids. There are hybrids sensitive to higher plant density and there are hybrids with wide and narrow optimum plant densities.

The agro-ecological optimum fertilizer dosage of hybrids with a longer season (FAO 400-500) was N 30-40 $\mathrm{kg} \mathrm{ha}^{-1}$ higher in favourable years as compared to early hybrids.

We can summarize our results by saying that we have to use hybrid-specific technologies in maize production. In the future, we have to increase the level of inputs and have to apply the best appropriate hybrids and with respect to the agroecologial conditions, we can better utilize the genetic yield potential.
\end{abstract}

\section{INTRODUCTION}

Regarding the yield, three eras can be differentiated in the history of maize production in Hungary. From 1921 until 1980, maize yield increased linearly and from the 1980s until the change of the regime, it reached, then exceeded $6 \mathrm{t} \mathrm{ha}^{-1}$. This significant development was due to the increased use of chemicals, improvement of the technology, modern hybrid use and last but not least the breeding and research work performed at the Hungarian research bases. Nowadays, the yields are not so favourable, the yield fluctuation can reach even 30$60 \%$.

There have been significant changes in the utilization of maize also. In the last years, its utilization for animal feeding has reduced and the industrial use, especially as a basic material for bioethanol production, has increased. In the past years, the possibility of intervention created a certain market for the growers, but the intervention purchase by the Union was stopped and bioethanol production did not fulfill the hopes. The changes in the utilization of maize modify the quality and inner content requirements also. As a feedingstuff, high protein content is required, while for industrial use high carbohydrate content should be targeted.

Maize yields are largely dependent upon nutrient supply, sowing date and plant density. The effect of these three factors is also influenced by the close correlation between ecological and biological factors.

In earlier years, Hungary was one of the leading countries in the world as regards the yields achieved in maize production (Menyhért, 1979), but at present besides unfavourable changes in climatic conditions, the level of NPK fertilization has also decreased.

In the $1980 \mathrm{~s}, 278 \mathrm{~kg} \mathrm{ha}^{-1}$ NPK active ingredients were applied, which decreased to $37 \mathrm{~kg} \mathrm{ha}^{-1}$ by 1991 . In 2002 , the amount applied was $70 \mathrm{~kg} \mathrm{ha}^{-1}, 80-90 \%$ of which was $\mathrm{N}$, while $\mathrm{P}$ and $\mathrm{K}$ replenishment was neglected. Kádár (2000) drew attention to the fact that fertilization should aim at supplementing deficient nutrients. Therefore, when planning fertilization, the amount of nutrients removed by the yield should be taken as the basis. According to Sárvári (1995), if both efficacy and environmental aspects are considered, the most favourable rate of $\mathrm{N}$ for maize on meadow soil is $60-120 \mathrm{~kg} \mathrm{ha}^{-1}$ active ingredient, depending on the forecrop and the year.

In experiments at Martonvásár from 1988 until 1992, Berzsenyi (1993) obtained maximum maize biomass production and the highest absolute growth rate in treatments given 160 or $240 \mathrm{~kg} \mathrm{~N} \mathrm{ha}^{-1}$. The biomass production and growth rates recorded in these treatments did not significantly differ in rainy years.

Based on the results of several years, Sárvári (1986) stated that, besides nitrogen, potassium is the most important nutrient on meadow soil.

Debreczeni (1990) claimed that a proper potassium supply increased photosynthetic activity, making, it important for both yield quantity and quality.

Menyhért (1979) found that the amount of nutrient uptake by maize during the vegetation period was N 264 $\mathrm{kg} \mathrm{ha}^{-1}, \mathrm{P}_{2} \mathrm{O}_{5} 110 \mathrm{~kg} \mathrm{ha}^{-1}$ and $\mathrm{K}_{2} \mathrm{O} 264 \mathrm{~kg} \mathrm{ha}^{-1}$ at a grain yield of $11 \mathrm{t} \mathrm{ha}^{-1}$. 
Németh and Széll (1985) mentioned that the variety policy followed in Hungary is open to varieties from all over the world. The cultivation of better varieties or hybrids accounts for $50 \%$ of the yield increase.

Optimal sowing time is largely influenced by climatic and soil conditions and is determined by the chilling resistance of the hybrid at germination.

The results of experiments in Martonvásár showed that the yield of maize sown in mid-April was $7 \%$ higher than that of maize sown in mid-May. The results indicated that a one-month delay in sowing resulted in the plants maturing 11-16 days later (14 days on average).

In experiments on the growth dynamics of 5 hybrids with different vegetation periods, Berzsenyi et al. (1998) found that earlier sowing enhanced reproductive growth, while later sowing increased the early vegetative growth. They also determined that a one-week delay in sowing resulted in a 3-week delay in silking.

Sárvári and Futó (2001) found a close correlation between sowing time and both yield and grain moisture content at harvest. The relationship between sowing time and yield was highly influenced by the distribution of precipitation during the vegetation period. Earlier sowing reduced the grain moisture content at harvest by 5-8\%, which is a great advantage from the aspect of economic production.

Széll and Csala (1984) found that, besides the response of the hybrid to increased plant density, the achievement of optimal plant density was primarily dependent upon the water and nutrient supplies.

Széll et al. (1986) stated that an over-dense plant population resulted in water deficiency. In most cases it caused a reduction of yield and reduced yield stability.

The results of Ruzsányi (1987) indicated that maize stands of 80000-90000 plants ha ${ }^{-1}$ require $50-70 \mathrm{~mm}$ more water than less dense stands. Considering the water supplies currently available, moderation is advisable when determining the number of plants per hectare.

Berzsenyi (1994) stated that grain yield gradually increased until the optimal plant density was reached, after which it started to decrease. In wet and dry years, the optimal plant density of the same hybrid was 80000 and 50000 plants $\mathrm{ha}^{-1}$, respectively. The increase in plant density resulted in a consistent reduction in the harvest index.

According to Sárvári (2001), due to the increase in the frequency of dry years and the lower nutrient supply, plant densities of 68000-72000 plants ha ${ }^{-1}$ and 60000-65000 plants ha ${ }^{-1}$ are more suitable for FAO 200-300 and FAO 400-500 hybrids, respectively, than the 80000-90000 plants ha $^{-1}$ suggested in the seventies and eighties.

\section{MATERIALS AND METHODS}

The soil of our experimental projects was meadow soil. The soil could be characterized by high clay content and pour phosphorus and medium potassium contents. Among the soil characteristic parameters it is important that the phosphorus and potassium fixation are very high.

In the last decade, from ten years six years were dry and hot in our region (figure 1). So the importance of crop-rotation is increasing and we have to intend to use appropriate crop rotation.

The water demand of maize is fairly moderate, but the sensibility of maize to drought is high among the field crops.

Figure 1: Annual mean temperatures and precipitation sums in Hungary between 1901 and 2008
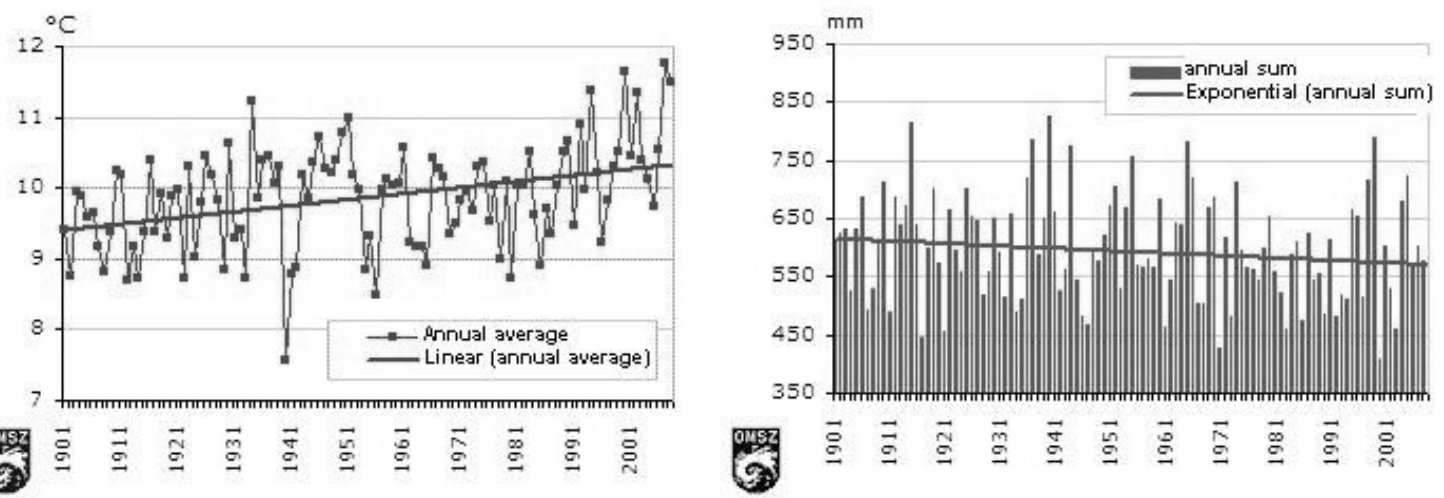

(Based on the homogenized and interpolated data of 15 stations), Source: National Meteorological Service

The yield changes of maize produced in crop-rotation and monoculture were studied on the basis of data collected from field experiments on meadow soil. The experiments are part of the National Long-Term Fertilization Experiment started in 1966.

Applied crop-rotations in the experiment:

- Triculture: pea - wheat - maize - maize

- Biculture: wheat - maize - wheat

- Monoculture: since 1966 
The applied dosages of artificial fertilisers were: 0-250 kg ha ${ }^{-1} \mathrm{~N}, 0-200 \mathrm{~kg} \mathrm{ha}^{-1} \mathrm{P}_{2} \mathrm{O}_{5}, 0-200 \mathrm{~kg} \mathrm{ha}^{-1} \mathrm{~K}_{2} \mathrm{O}$. The nitrogen was applied in autumn and spring, while the total amount of phosphorous and potassium were applied in one dosage in autumn.

In the plant density and sowing time experiments, the standard nutrient supply was $110 \mathrm{~kg} \mathrm{ha}^{-1} \mathrm{~N}, 80 \mathrm{~kg} \mathrm{ha}^{-1}$ $\mathrm{P}_{2} \mathrm{O}_{5}$ and $130 \mathrm{~kg} \mathrm{ha}^{-1} \mathrm{~K}_{2} \mathrm{O}$. The plant densities were $45,60,75$ and 90 thousand plants ha ${ }^{-1}$.

The results were evaluated by analysis of variance and parabolic regression analysis.

\section{RESULTS AND DISCUSSION}

The yields of maize in monoculture crop rotation decreased by $1-3 \mathrm{t} \mathrm{ha}^{-1}$ in each dry year during the experiment (1983, 1990, 1992, 1993, 1994, 1995, 1998, 2000, 2003 and 2007). The most favourable forecrop of maize was wheat, medium was the biculture crop rotation and the worst crop rotation was the monoculture (figure 2).

Figure 2: Effects of forecrops on maize yields 1976-2000

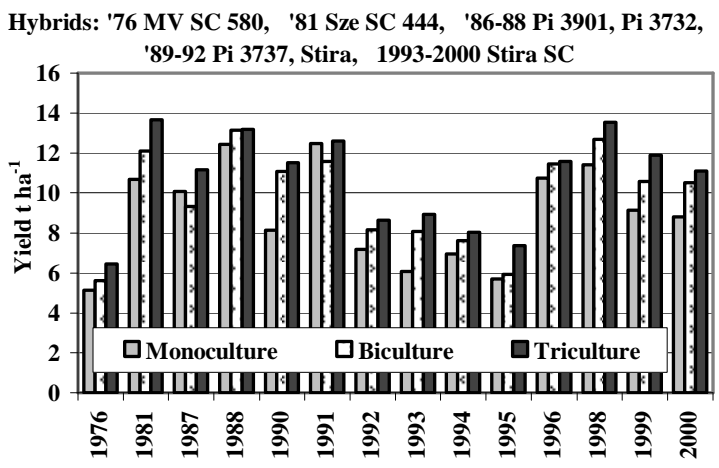

The forecrop determined the doses of fertilizers, it mainly influenced the doses of nitrogen (table 1). In triculture (peas - wheat - maize) crop rotation (after wheat forecrop) the optimum N-dose was 50-60 kg ha ${ }^{-1}$, and in monoculture the optimum $\mathrm{N}$-doses increased to $100-120 \mathrm{~kg} \mathrm{ha}^{-1}$ (of course we had to apply appropriate phosphorus and potassium doses as well).

Optimal fertiliser doses for corn $\mathrm{kg} \mathrm{ha}^{-1}$ effective material

Table 1:

\begin{tabular}{|l|c|c|c|c|}
\hline Forecrops & $\mathrm{N}$ & $\mathrm{P}_{2} \mathrm{O}_{5}$ & $\mathrm{~K}_{2} \mathrm{O}$ & TOTAL \\
\hline $\begin{array}{l}\text { Wheat } \\
\text { (in triculture) }\end{array}$ & $50-60$ & 45 & 55 & $150-160$ \\
\hline $\begin{array}{l}\text { Wheat } \\
\text { (in biculture) }\end{array}$ & $60-80$ & 45 & 55 & $160-180$ \\
\hline Maize & $80-100$ & 90 & 110 & $280-300$ \\
\hline $\begin{array}{l}\text { Maize } \\
\text { (in } \\
\text { monoculture) }\end{array}$ & $100-120$ & 90 & 110 & $300-320$ \\
\hline
\end{tabular}

By using about 200-250 kg nitrogen fertilizer the $\mathrm{NO}_{3}$ content of 100 and $120 \mathrm{~cm}$ soil layer varies between $10-50 \mathrm{mg} \mathrm{kg}^{-1}$. We obtained lower $\mathrm{NO}_{3}$ values in crop rotation experimental projects, the monoculture crop rotation was characterized by higher values (which means 125 and $175 \mathrm{mg} \mathrm{kg}^{-1} \mathrm{NO}_{3}$ content). In our long-term experiments, the $\mathrm{pH}$ values decreased when we use high doses of fertilizers (figure 3 ).

Figure 3: The effect of $\mathbf{N}$ fertilization on the $\mathrm{NO}_{3}-\mathrm{N}$ content in soil

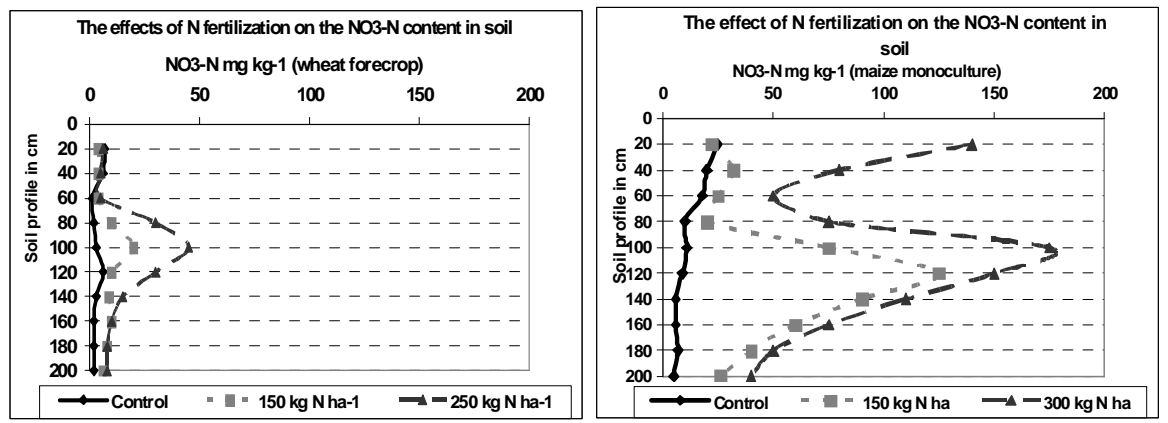


In monoculture crop rotation the soil fertility and the microbiological activity of soil is decreased. The yield decrease of maize in monoculture could be explained on one hand by the utilization of soil available water capacity. That is why we recommend crop rotation after 3-4 years of monoculture.

A lot of elements determined the harvest grain moisture of maize. Our experiments proved that with early planting time with optimum fertilizer doses and lower plant density, maize lost water faster, so we could harvest the different maize genotypes at lower moisture.

The Cold-test values describe the different genotypes' tolerances to cold, so this parameter is very important in determining sowing time.

The hybrids marked by blue lines have high Cold-test values (94-96\%) and so these hybrids could be planted earlier.

There is a strong correlation between the sowing time and the yield of maize hybrids, but this interactive effect can be modified by the amount and distribution of precipitation in vegetation period. There is a stronger, even significant correlation between planting time and grain moisture at harvest time.

At early sowing time, the grain moistures were less by $5-12 \%$ lower compared to the late sowing time and 4$5 \%$ lower compared to the optimum planting treatment (figure 4).

Figure 4: Moisture contents of maize hybrids in 1999

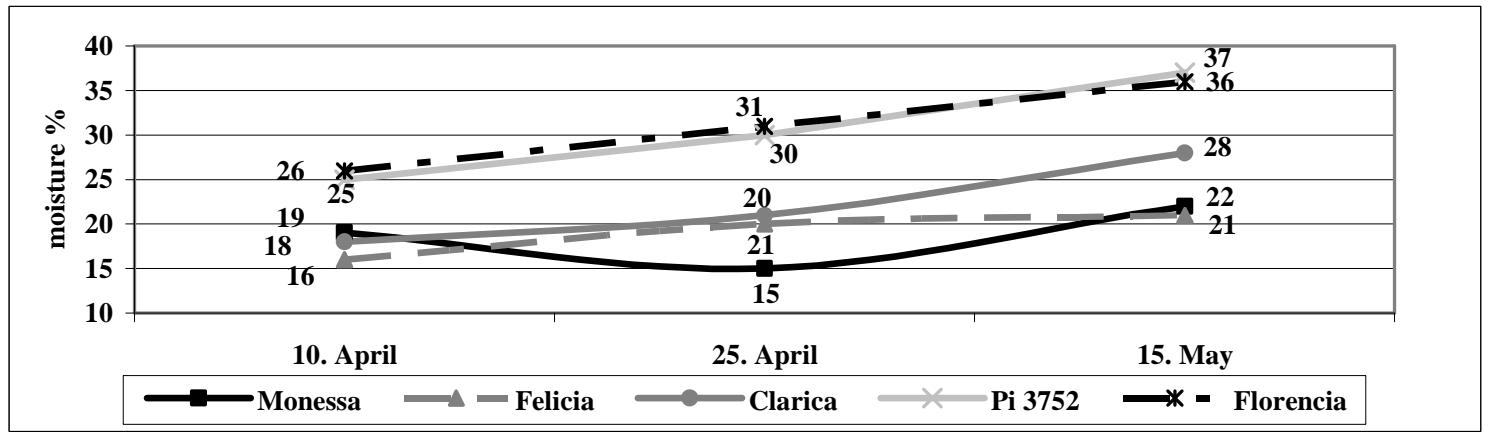

The optimum plant density depends on the genotype of hybrids, on agroecological conditions, on the effects of crop year, on the water- and nutrient supply and on the intensity of production. A change of 10 thousand plants ha ${ }^{-1}$ in stock density can increase yields by $1.5-2 \mathrm{t} \mathrm{ha}^{-1}$, but over the optimum level yields are reduced.

There are big differences among the plant densities of different maize hybrids. There are hybrids sensitive to higher plant density and there hybrids of wide and narrow plant density optimum.

Considering the fact that the frequency of dry crop years increased and the usage of fertilizers dropped in the last ten years, we suggest that the optimum plant density is 68-72 thousand ha $^{-1}$ in the case of 200-300 FAO hybrids and 60-65 thousand $\mathrm{ha}^{-1}$ in 400-500 FAO hybrids.

To develop the genetic background of maize, we continuously test the different maize hybrids by using special methods developed by Bocz (1974) and we evaluate the cropping ability of hybrids, the natural nutrient utilization ability and the fertilizer-response of hybrids.

It is very useful for the practice that the new up-to-date hybrids combine the good natural nutrient utilization ability with good fertilizer utilization ability, so the modern maize hybrids can be characterized by good fertilizer response.

From the aspects of effectiveness and environmental protection the optimum fertilizer doses of maize hybrids are $\mathrm{N} 60-120, \mathrm{P}_{2} \mathrm{O}_{5} 45-90, \mathrm{~K}_{2} \mathrm{O} 53-106 \mathrm{~kg} \mathrm{ha}^{-1}$ depending on fore crop and crop year.

\section{CONCLUSIONS}

We can summarize our results by saying that we have to use hybrid-specific technologies in maize production. In the future, we have to increase the level of inputs and have to apply the best appropriate hybrids and taking into consideration the agroecologial conditions we can better utilize the genetic yield potential.

\section{REFERENCES}

Berzsenyi Z. (1993): A N mütrágyázás és az évjárat hatása a kukorica hibridek szemtermésére és N mütrágya-reakciójukra tartamkísérletben. (The effect of $\mathrm{N}$ fertilization and the year on the grain yield and $\mathrm{N}$ fertilizer response of maize hybrids in a long-term experiment.) Növénytermelés, 42, 49.

Berzsenyi Z. (1994): A növényszám és az évjárat hatása a kukoricahibridek szemtermésére és terméskomponenseire, valamint növényszám reakciójára. (The effect of plant density and the year on the grain yield and yield components and plant density response of maize hybrids.) Kukoricatermesztés. 1994. Országos Tanácskozás. Budapest. pp. 75-82.

Berzsenyi Z.-Ragab A. Y.-Dang, Q. L. (1998): A vetésidő hatása a kukoricahibridek növekedésének dinamikájára 1995-ben és 1996-ban. (The effect of sowing time on the growth dynamics of maize hybrids in 1995 and 1996.) Növénytermelés, 47, 165-180.

Debreczeni B. (1990): Kálium a növénytermesztésben. (Potassium in crop production.) Magyar Mezőgazdaság, 45, 10-12. 
Kádár I. (2000): A kukorica tápelem-felvétele és trágyaigénye. (Nutrient uptake and nutrition requirements of maize.) Gyakorlati Agrofórum, $11,41$.

Menyhért Z. (1978): Kukoricáról a termelőknek. (About the maize for the producers.) Mezőgazdasági Kiadó. Budapest. 155-167.

Németh J.-Széll S. (1985): Kukoricatermesztés fejlesztése. (The improvement of maize production.) MÉM Mérnök- és Vezetőtovábbképző Intézet Kiadványa, Budapest. pp. 5-22.

Ruzsányi L. (1987): Agrotechnika a kukoricatermesztésben. (Agronomic techniques in maize production.) Magyar Mezőgazdaság, 42, 8-9.

Sárvári M. (1986): A vetésváltás és a tápanyagellátás hatása a búza és a kukorica termésére. (The effect of crop rotation and nutrient supply on the yield of wheat and maize.) Ph.D. Thesis, Debrecen.

Sárvári M. (1995): A tőszám szerepe a fajtaspecifikus kukorica-termesztési technológiában. (The role of plant density in the cultivar-specific maize production technology.) Növénytermelés, 44, 261-270.

Sárvári M. (2001): Összefüggés a kukoricahibridek töszáma és termése között. (The relationship between the plant density and yield of maize hybrids.) II. Növénytermesztési Tudományos Nap. Integrációs feladatok a hazai növénytermesztésben. Budapest, Magyar Tudományos Akadémia. P. 12.

Sárvári M.-Futó Z. (2001): A vetésidő hatása a különböző genetikai adottságú kukoricahibridek termésére. (The effect of sowing time on the yields of maize hybrids with differing genetic characteristics.) Növénytermelés, 50, 43-60.

Széll E.-Csala G. (1984): Az aszály hatása a kukoricára. (The effect of drought on maize.) Magyar Mezögazdaság, 38, 9.

Széll E.-Tátrai J.-Székely Cs.-Rózsás A.-Táczi J. (1986): Kukorica üzemi tőszámkísérletek. (Plant density experiments with maize.) Magyar Mezőgazdaság, 41. 10-11. 